\title{
Impact of Herbicides on Various Weed Flora in Wheat under Rainfed Production System
}

\author{
Bogale Ayana* and Meseret Ejeta \\ Ethiopian Institute of Agricultural Research, Holeta Agricultural Research Center, Holeta, Ethiopia \\ *Corresponding Authors: Bogale Ayana, Ethiopian Institute of Agricultural Research, Holeta \\ Agricultural Research Center, Holeta, Ethiopia
}

\begin{abstract}
Bread wheat is the most important cereal food grain crops in the world which can be grown under diverse agro ecology. However, its productivity has been limited due to various abiotic and biotic factors including weeds. The aim of the study was to evaluate the effects of post emergence broad leaf herbicides application on weed management and productivity of wheat. Four types of herbicides 2,4-D1lt ha-1,Pyroxulam

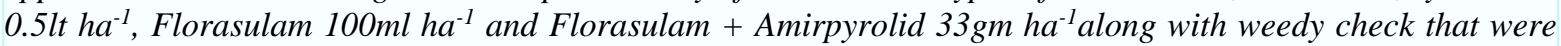
laid out in Randomized Completely Block Design with three replications. A total of identified 12 weed species were recorded $86 \%$ broad and $14 \%$ grass weeds. Relative weed density also indicated that the field was highly infested by Galinsoga pulviflora Cav. but the lowest infestation of Guizotia scabra(Vis) Chiov was recorded in the field. Results also revealed that significant effects of post emergence herbicides application on some traits studied but there is no significant difference among tested herbicides on plant height, stand count, spike length, number of seeds per spike and thousand grain weights except for weedy checks. The minimum dry biomass weeds (111.00 $\left.\mathrm{kg} \mathrm{ha}^{-1}\right)$ and the highest weed control efficiency (79.63\%) were recorded from the Pyroxulam. The highest number of productive tillers $\left(131.66 \mathrm{~m}^{-2}\right)$,stand count $\left(413.00 \mathrm{~m}^{-2}\right)$, seeds per spike(71.58), thousand grain weight (42.00g),grain yield (3928.25 $\left.\mathrm{kgha}^{-1}\right)$ and biological yield (8693.3 $\left.\mathrm{kg} \mathrm{ha}^{-1}\right)$ were recorded from Florasulam + Aminopyrolid while the lowest values were observed from the weedy check. Therefore, it can be concluded that Florasulam + Aminopyrolid effectively managed weeds and gave maximum yield which could be recommended for the test environment.
\end{abstract}

Keywords: application, effect, herbicides, maximum, weedy check

\section{INTRODUCTION}

Wheat (Triticum aestivum L.) is the most important cereal crop cultivated worldwide and there by sustaining the livelihood of the world hungrier (Yared et al., 2018). It is produced in a wide range of climatic environments and geographic regions (Dixon et al., 2009). Despite its importance in Ethiopia, the mean national yield is 1.3 tons $\mathrm{ha}^{-1}$ which is $24 \%$ below the mean yield of Africa and $48 \%$ below the global mean yield of wheat (Gebre-Mariam,2003). Weeds are one of the major constraints in wheat production as they reduce productivity due to competition, allelopathy and by providing habitats for pathogens as well as serving as alternate host for various insects, fungi and increase harvest cost (Abbas et al.,2009).Studies indicated that crop losses due to weed competition throughout the world as a whole are greater than those resulting from combined effect of insect pests and diseases. The losses caused by weed infestations vary depending up on the weed species, their density and environmental factors.

Physical methods are laborious, tiresome and expensive due to increasing cost of labor, draft animals and implements. However, the choice of most appropriate herbicide, proper time of application and proper dose is an important consideration for lucrative returns (Khalil, et al., 2008). The use of herbicide is considered to be the most viable option for controlling weeds in wheat production. Weeds are one of the major factors reducing crop yield, deteriorate quality of crops and reduce farmers' income (Yared et al., 2018).

The worldwide expansion in wheat cultivation and food production facilitated the use of agrochemicals particularly chemical fertilizers and herbicides. Hand weeding and other traditional control methods are time consuming and involve high labor cost. Chemical weed control method offers an 
advantage to save time, labor and money. This method become popular in different parts of the developed world mainly due to scarcity or expensive labor during peak of growing season and relatively the lower weeding cost. Continuous use of a single herbicide or herbicides of the same family or mechanism of action eventually resulted in weed resistance, herbicide persistence as well as the buildup of toxic residues in food chain, toxic effects to humans and animals. Hence, evaluation of new herbicides having the ability of controlling various weed species is essential. Therefore, the aim of the study was to evaluate the effects of post emergence broad leaf herbicides application on weed management and productivity of wheat.

\section{MATERIALS AND METHODS}

\section{Description of the study area}

Field experiment was conducted at Holeta Agricultural Research Center which is located $33 \mathrm{~km}$ west of Addis Ababa at $9^{\circ} \mathrm{ooN}$ latitude and longitude $38^{\circ} 30 \mathrm{E}$ and elevation of $2400 \mathrm{~m}$.a.s.l. during main cropping season (July, 2019 to January, 2020). The area is receiving mean annual rain fall is $1144 \mathrm{~mm}$ with mean temperature maximum $22^{\circ} \mathrm{c}$ and minimum $6^{\circ} \mathrm{c}$.The soil of the type is clay loam in texture with pH 6.65 , organic carbon $2.26 \%$, available P $14.17 \mathrm{mg} \mathrm{kg}^{-1}$ soil, total nitrogen $0.12 \%$ and cation exchange capacity, $17 \mathrm{Cmol} \mathrm{kg}^{-1}$ soils(HAR,2017).

\section{Treatments and experimental design}

The field was ploughed with tractor followed by harrowing to make fine seedbed. Wheat variety "Dendea" $100 \mathrm{~kg} \mathrm{ha}^{-1}$ seed rate was used as test crop. Treatments comprised of four herbicides 2,4-D amine $720 \mathrm{~g} / \mathrm{L}$, Pyroxulam, Florasulam, Florasulam +Aminopyrolid including weedy check and herbicides were applied as single post emergence. Experiment was laid out Randomized Complete Block Design with three replications. The size of each subplot was $4 \mathrm{~m} \times 3 \mathrm{~m}$ consisted of 15 rows each $4 \mathrm{~m}$ long and $20 \mathrm{~cm}$ apart from the adjacent row. All herbicides were applied with the help of knapsack sprayer with nozzle size of $350 \mu \mathrm{m}$ while volume of water $200 \mathrm{~L} \mathrm{ha}^{-1}$ pressurized at $40 \mathrm{psi}$. Herbicides were applied as post emergence at crop tillering stage i.e. about 30-35 days after crop emergence.

Table1.Trade names, common names and rate per hectare of different herbicides

\begin{tabular}{|l|l|c|}
\hline Trade name & Common name & Rate $^{-1}$ \\
\hline Agro 2,4 -D 720 g/l & $2,4-D$ & $1 \mathrm{~L}$ \\
\hline Pallas 45 OD & Pyroxulam & $0.5 \mathrm{~L}$ \\
\hline Derby 175 SC & Florasulam & $100 \mathrm{ml}$ \\
\hline Lancolet 450 WG & Florasulam +Aminopyrolid & $33 \mathrm{gm}$ \\
\hline
\end{tabular}

\section{Data collection}

The category wise broadleaved and grass weeds fresh biomass was done before harvest using $25 \mathrm{~cm} \mathrm{x}$ $25 \mathrm{~cm}$ quadrat thrown randomly at four places in each plot and converted into $\mathrm{m}^{2}$. The aboveground dry biomass of weeds harvested from each quadrat placed into paper bags separately and sun dried before drying in an oven at a $65{ }^{\circ} \mathrm{C}$ until constant weight and subsequently the dry weight measured. Weed control efficiency(WCE) was determined by the formula, $W C E \%=\frac{W D C-W D P}{W D C} X 100$ where, WCE=Weed Control Efficiency, WDC=Weed Dry weight in Control Plot and Weed Dry weight in Particular treatment (Davasenapathy et al.,2008).

Crop stand count per $\mathrm{m}^{2}$ was taken by throwing quadrat $25 \mathrm{~cm} \times 25 \mathrm{~cm}$ randomly at four places in each plot. Plant height was measured from 4 plants randomly selected in each plots and their average calculated .The numbers of productive tillers counted from five rows with the length of $1 \mathrm{~m}$ randomly taken in each net plot area and was converted into $\mathrm{m}^{2}$ at harvest. The number of grains per spike was determined from randomly taken 4 spikes per plot. The spike length was measured from randomly selected 4 plants in each plot. Thousand grains weight was counted from the bulk of threshed produce from the net plot area and their weight recorded. Grain yield $\left(\mathrm{kg} \mathrm{ha}^{-1}\right)$ was measured after threshing the sun dried plants harvested from each net plot and the yield was adjusted at $12.5 \%$ grain moisture content (Amare et al., 2014). Biological yield was determined by taking the total weight of the harvest from each net plot area after sun drying the whole aboveground biomass. 
The harvest index and yield loss were also calculated. The harvest index calculated by the formula, $H I \%=\frac{\text { Grain yield }}{\text { Total aboveground dry biomass }} X 100$ and yield loss was calculated by the formula, YL\% $=\frac{M G Y T-G Y P T}{M G Y T} X 100, \mathrm{YL}=$ Yield Loss, MGYT=Maximum Grain Yield from Treatments and GYPT=Grain Yield of Particular Treatment.

\section{Data analysis}

Statistical analysis: Data recorded was subjected to ANOVA using statistical analysis system (SAS) as per design and the means was separated by LSD test at $5 \%$ or $1 \%$ (Gomez K.A. and A.A. Gomez, 1984).

\section{RESULTS AND DISCUSSION}

\section{Weed Species composition in the experimental field}

The weed community comprised of both broadleaf and grass weeds that were classified in to eight major families. Out of total weeds species present in the experimental field $86 \%$ were annual broadleaf weeds while $14 \%$ were annual grasses weeds. The maximum relative weed density in the field was G.pulviflora (31.39\%) followed by P.nepalense (25.50\%) while minimum relative weed density (2.00\%) was recorded from G.scabra and P.paradoxa L. (Table -2).

Table2. Weed flora, density and their life form

\begin{tabular}{|l|l|l|l|l|}
\hline Scientific names & Families & $\begin{array}{l}\text { Weed density } \\
\mathrm{m}^{-2} \text { before spray }\end{array}$ & $\begin{array}{l}\text { Relative } \\
\text { Weed } \\
\text { Density } \\
(\%)\end{array}$ & Life form/category \\
\hline Arthraxon prinodes L. & Poaceae & 7.02 & 5.11 & Annual (grass) \\
\hline Setaria pumila L. & Poaceae & 10.44 & 7.60 & Annual (grass) \\
\hline Phalaris paradoxa L. & Poaceae & 2.00 & 1.45 & Annual (grass) \\
\hline Galinsoga pulviflora Cav. & Compositae & 31.39 & 22.88 & Annual (broad leaf) \\
\hline Corrigiola capensis Wild & Caryophylaceae & 16.24 & 11.83 & Annual (broad leaf) \\
\hline $\begin{array}{l}\text { Guizotia } \\
\text { scabra } \text { Vis)Chiov }\end{array}$ & Compositae & 2.00 & 1.45 & Annual (broad leaf) \\
\hline Oxalis corniculata HBK & Oxalidaceae & 9.00 & 6.56 & Annual (broad leaf) \\
\hline Plantago lanceoleta L. & Plantaginaceae & 6.30 & 4.60 & Annual (broad leaf) \\
\hline Polygonum nepalense L. & Polygonaceae & 25.50 & 18.58 & Annual (broad leaf) \\
\hline Raphanus raphanistrum L. & Brassicaceae & 5.30 & 3.86 & Annual (broad leaf) \\
\hline Spergula arvensis L. & Caryophylaceae & 6.50 & 4.74 & Annual (broad leaf) \\
\hline Cyanotis barbata D.Don Don & Commelinaceae & 15.50 & 11.30 & Annual (broad leaf) \\
\hline
\end{tabular}

\section{Dry biomass of weed}

The applications of herbicides were significant on dry biomass of weeds. The highest dry biomass of weeds (556.66 kg ha-1) was recorded in weedy check whereas the minimum $\left(111.00 \mathrm{~kg} \mathrm{ha}^{-1}\right)$ was recorded due to Pyroxulam application (Table-3).

The application of herbicides 2, 4-D, Florasulam and Florasulam + Amirpyrolid revealed that statistically no significant difference. The minimum dry biomass of broad leaf weeds at Pyroxulam might be related to the activity of broad spectrum herbicides and also due to the ability of the herbicide in reducing weed density by killing both broadleaf and narrow leaf weeds by affecting the physiological process of those weeds resulted in mortality of weeds that remained in field.

This finding was similarly with Nadeem et al. (2006) and Munsif et al. (2009) who concluded that maximum weed density in weedy check can be attributed to unchecked growth, while application of herbicide caused mortality of weed resulting in lower weed density at harvest.

\section{Weed control efficiency}

Weed control efficiency was influenced by herbicides application. The maximum weed control efficiency was recorded at Pyroxulam (79.63\%) while no weed control efficiency at weedy check (Table -3).The application 2, 4-D, Florasulam and Florasulam + Amirpyrolid revealed that statistically no significant difference. The higher weed control efficiency at Pyroxulam might be related to lowest 
dry biomass of weeds which exhibited that the ability of the herbicides killing various weeds species in wheat.

Furthermore, the result also revealed that broad spectrum herbicides increased weed control efficiency due to limited weed growth but at low weed control efficiency as a result of severe inter and intra specific competition and higher weed biomass. This might be related to the activity of broad spectrum of the herbicide against both broad and grassy weeds as compared to other herbicides application. These findings are similar with who reported that herbicides with broad spectrum provided better weed control efficiency than control treatment

(Ashiq et al.,2007).Tana et al. (2018) reported that the high control efficiency indicated that the weed were controlled when they are young or before they accumulated more dry matter by competing with the crop plants.

Table3. Effects of herbicides on dry biomass of weeds and weed control efficiency

\begin{tabular}{|l|l|l|}
\hline Treatments & Dry biomass of weeds $\left(\mathrm{kg} \mathrm{ha}^{-1}\right)$ & Weed control efficiency $(\%)$ \\
\hline $2,4-\mathrm{D}$ & $158.33 \mathrm{~b}$ & $71.58 \mathrm{~b}$ \\
\hline Pyroxulam & $111.00 \mathrm{c}$ & $79.63 \mathrm{a}$ \\
\hline Florasulam & $153.33 \mathrm{~b}$ & $72.64 \mathrm{~b}$ \\
\hline Florasulam + Aminopyrolid & $153.33 \mathrm{~b}$ & $72.45 \mathrm{~b}$ \\
\hline Weedy check & $556.66 \mathrm{a}$ & $0.00 \mathrm{c}$ \\
\hline LSD & 22.21 & 4.64 \\
\hline CV $(\%)$ & 5.21 & 4.16 \\
\hline
\end{tabular}

Plant height

The application of different herbicides had significant effect on plant height. The maximum plant height was recorded from weedy check plots $(111.08 \mathrm{~cm})$ followed by $2,4-\mathrm{D}(105.00 \mathrm{~cm})$ while the minimum plant height $(102.33 \mathrm{~cm})$ was obtained from application of Florasulam + Amirpyrolid (Table- 4).

The application of all herbicides except for weedy check showed that statistically no significant differences. The tallest plants $111.08 \mathrm{~cm}$ at weedy check indicated that the competition of weeds. The result clearly showed that plant attained its maximum height where the competition was severe for light between crop as well as weed but at lower competition, plant could not invest larger resources to attain its maximum height. Similar findings was reported from Bibi et al (2008) who reported that in weedy check the wheat crop invested photosynthate in attaining the vegetative superiority by shading weeds. These findings was contradicted with the work reported by Khalil et al. (2009) who concluded that plant height is strongly under genetic control and but not affected by herbicides application. Plant height is a varietal character more affected by the genotype than by the environment. However, interaction of factors to some extent significantly altered plant height (Safdar et al., 2011).

\section{Number of fertile tillers}

The numbers fertile tillers $\mathrm{m}^{-2}$ was significantly affected by different herbicidal application. Maximum number of fertile tillers $\left(131.66 \mathrm{~m}^{-2}\right)$ were recorded from application of Pyroxulam while the minimum number of fertile tillers $\left(35.66 \mathrm{~m}^{-2}\right)$ was recorded at weedy check plots (Table - 4).

The application of 2,4-D and Pyroxulam and Florasulam caused statistically no significant difference. The maximum number of fertile tillers at Pyroxulam could be related with lower dry biomass of weeds, better weed control efficiency that resulted in less inter and intra specific completion of weeds with crop plants for water, nutrients and other growth factors and also due to the optimum space for wheat plants to flourish and produce fertile tillers up to their potential but the probable reason of lower number of fertile tillers in other interaction could be grasses escaped from their phytotoxicity and were competitive with wheat resulting in lower tillers. Lower number of fertile tillers in weedy check treatment can be attributed to higher weed density that resulted in competition for plant growth resources.

Dalga (2016) reported similar results that under low competition between weeds and crop for resources that enhanced productive tillers. Asad et al. (2017) also stated that increase in number of fertile productive tillers relatively better weed control which ultimately facilitated by more translocation of photosynthate towards reproductive growth due to lower weed wheat competition. 
Hussein et al.(2013) also reported that effective weed control methods could reduce dry matter of weed and increased number of wheat productive tillers.

\section{Stand count}

The stand count $\mathrm{m}^{-2}$ was significantly affected by different herbicidal application. Maximum number of stand count $\left(413.00 \mathrm{~m}^{-2}\right)$ were recorded from application of Pyroxulam while the minimum number of stand count $\left(130.00 \mathrm{~m}^{-2}\right)$ was recorded at weedy check plots (Table - 4).

The application all tested herbicides caused statistically no significant difference on stand count except for weedy checks. The maximum number of stand count at Pyroxulam could be related with lower dry biomass of weeds, better weed control efficiency that resulted in less inter and intra specific completion of weeds with crop plants for water, nutrients and other growth factors and also due to the optimum space for wheat plants to flourish and produce fertile tillers up to their potential that contributed more number of stand count but the probable reason of lower number of fertile tillers in other interaction could be grasses escaped from their phytotoxicity and were competitive with wheat resulting in lower tillers. Lower number of stand count in weedy check treatment can be attributed to higher weed density that resulted in competition for plant growth resources.

Dalga (2016) reported similar results that under low competition between weeds and crop for resources that enhanced productive tillers which contributed increase in stand count. Asad et al. (2017) also stated that increase in number of fertile productive tillers relatively better weed control which ultimately facilitated by more translocation of photosynthate towards reproductive growth due to lower weed wheat competition. Hussein et al. (2013) also reported that effective weed control methods could reduce dry matter of weed and increased number of wheat productive tillers.

Table4. Effects of herbicides on plant height, number of tillers and stand count

\begin{tabular}{|l|l|l|l|}
\hline Treatments & Plant height & Number of tillers & Stand count \\
\hline $2,4-\mathrm{D}$ & $105 \mathrm{~b}$ & $128.33 \mathrm{ab}$ & $409.33 \mathrm{a}$ \\
\hline Pyroxulam & $103.33 \mathrm{~b}$ & $131.66 \mathrm{a}$ & $413.00 \mathrm{a}$ \\
\hline Florasulam & $103.75 \mathrm{~b}$ & $128.66 \mathrm{ab}$ & $407.66 \mathrm{a}$ \\
\hline Florasulam+Aminopyrolid & $102.33 \mathrm{~b}$ & $126.66 \mathrm{~b}$ & $406 \mathrm{a}$ \\
\hline Weedy check & $111.08 \mathrm{a}$ & $35.66 \mathrm{c}$ & $130 \mathrm{~b}$ \\
\hline LSD & 6.01 & 4.91 & 7.5 \\
\hline CV $(\%)$ & 3.03 & 2.36 & 1.12 \\
\hline
\end{tabular}

\section{Spike length}

The application of different herbicides had significant effect on the spike length of wheat. The highest spike length was recorded from application of Pyroxulam $(9.58 \mathrm{~cm})$ followed by the application of 2,4-D $(9.16 \mathrm{~cm})$ but the lowest spike lengths were recorded at weedy check (Table-5). The application of all tested herbicides produced statistically no significant difference except weedy check. The maximum spike length recorded at Pyroxulam could be related to effective weed control that resulted in better growing conditions for the crop to utilize resources effectively to produce longer spikes but at weedy check due to severe competition shorter spikes produced.

Similar result was reported from Tana et al. (2018) continuous increase in spike length which might be attributed to relief of wheat plants from weed competition leading to better growing conditions and more resources availability to the wheat plants. Asad et al. (2017) also stated that increase in spike length attributed to minimum crop - weed competition in treated plots and more availability of moisture that cause healthy plant growth.

\section{Number of seeds per spike}

The application herbicides had no significant effect on number of seeds per spike except for weedy check. The maximum numbers of seeds per spike were counted at application of Florasulam + Aminopyrolid (71.58) whereas minimum number of seeds per spike was counted from weedy check plot (Table - 5).

The highest number of seeds per spike at application of Florasulam + Aminopyralid might be related to lower dry weed biomass, better weed control efficiency that contributed to the crop to have longer 
spikelets for producing more number of seeds. Lower number of seeds per spike can be attributed to shorter spike length in weedy check plots due to severe crop-weed competition.

Similar results have also been reported by Pandey et al. (2007) increase in number of grains per spike can be attributed to availability of nutrients and greater spike length of wheat. According to Ali et al. (2014) the number of seeds per spike increased with decreased weed competition. The poor grain filling due to presence of weeds was reported to be due to reduced tillering, ear formation, and stem weight and height reduction in wheat (Fazal et al., 2012).

\section{Thousand grain weight}

The application of different herbicides did not impose significant effect on thousand grain weight except for weedy check. Maximum thousand grain weight was recorded at application of Florasulam $(42.00 \mathrm{~g})$ while minimum number of thousand grain weight was recorded at weedy check (Table - 5).

The highest thousand grain weight at Pyroxulam could be related to lower dry weed biomass, better weed control efficiency, minimum intra and inter-specific competition that enable the crop to utilize resources efficiently to produce well vigor seeds but at weedy check treatments lowest number of thousand grain weight was due to higher competition of plant growth resources that resulted in less vigor seeds. Similar results from Pandey et al. (2007) reported that lower thousand grain weight in weedy check and availability of nutrients and better plant growth might be the reason for heavier grains in high fertilizer levels.

Table 5. Effects of herbicides on spike length, number of seeds per spike and thousand grain weight

\begin{tabular}{|l|l|l|l|}
\hline Treatments & Spike length $(\mathrm{cm})$ & Seeds per spike & $\begin{array}{l}\text { Thousand } \\
\text { weight }(\mathrm{gm} .)\end{array}$ \\
\hline 2,4-D & & & $39.86 \mathrm{a}$ \\
\hline Pyroxulam & $9.08 \mathrm{a}$ & $66.50 \mathrm{a}$ & $41.20 \mathrm{a}$ \\
\hline Florasulam & $9.05 \mathrm{a}$ & $67.75 \mathrm{a}$ & $42.00 \mathrm{a}$ \\
\hline Florasulam + Aminopyrolid & $9.08 \mathrm{a}$ & $70.33 \mathrm{a}$ & $41.73 \mathrm{a}$ \\
\hline Weedy check & $7.58 \mathrm{a}$ & $71.58 \mathrm{a}$ & $31.86 \mathrm{~b}$ \\
\hline LSD & $6.66 \mathrm{~b}$ & $54.83 \mathrm{~b}$ & 3.77 \\
\hline CV $(\%)$ & 1.10 & 10.95 & 5.08 \\
\hline
\end{tabular}

\section{Grain yield}

The grain yield was significantly affected by the application of different herbicides. Maximum grain yield $\left(3928.25 \mathrm{~kg} \mathrm{ha}^{-1}\right)$ was obtained from Florasulam + Amirpyrolid while minimum grain yield $\left(1025.00 \mathrm{~kg} \mathrm{ha}^{-1}\right)$ was obtained from weedy check (Table -6$)$.

The application of 2,4-D and Pyroxulam showed that statistically no significant difference. Similarly application of Florasulam and Florasulam and Florasulam + Amirpyrolid showed that statistically no significant difference.

The highest number of grain yield at Florasulam + Amirpyrolid could be related to less weed competition with crop for plant growth factors and optimum space for wheat plants to flourish and produce fertile tillers up to their potential, more number of seeds per spike, thousand grain weight and higher number of total biomass production. The herbicide also had the ability of controlling various weed species and persistent. However, the lower grain yield at weedy check treatments was due to the severe inter and intra specific competition that resulted in lower yield and yield components.

The result of this study was similar with Nadeem et al. (2006) which stated that different herbicidal treatments had a significant effect on grain yield of wheat. The greatest reduction of yield was occurred when no herbicide was applied. Increased in yield in herbicides treated plots were due to the efficient weed control and thus the crop utilized all the available resources. These results are in confirmity with the work of Tunio et al. (2004) who reported that herbicidal treatments significantly increased grain yield in wheat. Ali et al. (2014) also stated that maximum grain yield was at weed free due to less weed population, better nutrient and water use efficiency but minimum at weedy check.

\section{Biological yield}

The application different post emergence herbicides highly influenced biological yield.

The maximum biological yield was obtained from the combination of Florasulam + Aminopyrolid 
$\left(8693.30 \mathrm{~kg} \mathrm{ha}^{-1}\right)$ while minimum biological yield $\left(4566.70 \mathrm{~kg} \mathrm{ha}^{-1}\right)$ was obtained from weedy check (Table - 6).

The use of all herbicides except Florasulam+ Aminopyrolid revealed that statistically no significant difference. The higher number of biological yield at Florasulam+ Aminopyrolid application could be related to less weed competition with crop plants for water, nutrients and other growth factors and also due to the optimum space for wheat plants to flourish and produce fertile tillers up to their potential, more number of seeds per spike and thousand grain weight that contributed to biological yield. However, the lowest biological yield at weed check signified severe competition of weeds resulted in fewer number of plants in plots.

Similar results were reported from Ali and Awan (2004) who stated that decreasing the biological yield in wheat might be due to weed competition as a consequence of depletion of nutrient supply and water by weeds, which resulted in reduced growth, seed and straw yields of crop plants. However, it is suggested that high seed rates were found to increase yield in well watered conditions, whereas the reverse was true with low soil moisture (Marwat et al., 2011).weed control methods increased biological yield of wheat reducing the weed infestation (Zahoor et al.,2012).

\section{Harvest index}

The application of different herbicides showed highly significant effect on harvest index. The highest harvest index (33.34\%) was observed at 2, 4-D.The minimum harvest index $(20.65 \%)$ was obtained from weedy check (Table - 6).

The application of all herbicides except Florasulam +Amirpyrolid showed that statistically no significant differences. The maximum number of harvest index at 2, 4-D might be related to higher in total biomass production. The result also clearly indicated that harvest index was lower at higher total biomass production. Similar findings were reported from Ali et al.(2014) and Amare et al.(2014) concluded that harvest index increased with decreased in weed competition. Sujoy et al. (2006) was also reported that significant variation in harvest index of wheat due to weed control treatments.

\section{Yield loss}

The uses of various post emergence herbicides were highly significant on yield loss of bread wheat. The use of Florasulam + Aminopyrolid gave the lowest yield loss (13.01\%) as compared to other tested herbicides but maximum yield loss $77.30 \%$ was obtained from weedy check plots (Table - 6).

The application of Florasulam and Florasulam + Amirpyrolid revealed statistically no significant differences. The lowest yield loss at Florasulam + Aminopyrolid could be related to higher weed control efficiency, more number of yield components and better crop growing conditions to produce higher yield. In contrast, higher weed biomass resulted in greatest yield reduction due to competition for growth resources and fewer number of wheat in the plots.

The highest yield loss obtained from weedy check plots as a result of higher weed density and competition. The finding was in conformity with the work of Amare et al(2014) reported that highest yield loss was at weedy check and under poor weed control. On the other hand, Karlen et al.(2002) reported a yield reduction as high as $80 \%$ in wheat due to weed competition throughout the crop growing season.

Table6. Effects of herbicides on grain yield, biological yield, harvest index and yield loss

\begin{tabular}{|l|l|l|l|l|}
\hline Treatments & $\begin{array}{l}\text { Grain yield } \\
\left.\mathrm{ha}^{-1}\right)\end{array}$ & $\begin{array}{l}\text { Biological yield } \\
\left(\mathrm{kg} \mathrm{ha}^{-1}\right)\end{array}$ & $\begin{array}{l}\text { Harvest index } \\
(\%)\end{array}$ & $\begin{array}{l}\text { Yield loss } \\
(\%)\end{array}$ \\
\hline 2,4-D & $3745.17 \mathrm{~b}$ & $7483.3 \mathrm{~b}$ & $33.34 \mathrm{a}$ & $17.07 \mathrm{~b}$ \\
\hline Pyroxulam & $3813.17 \mathrm{~b}$ & $7700 \mathrm{~b}$ & $33.12 \mathrm{ab}$ & $15.56 \mathrm{bc}$ \\
\hline Florasulam & $3838.83 \mathrm{ab}$ & $7900 \mathrm{~b}$ & $32.70 \mathrm{ab}$ & $14.99 \mathrm{bc}$ \\
\hline Florasulam+Aminopyrolid & $3928.25 \mathrm{a}$ & $8693.3 \mathrm{a}$ & $31.17 \mathrm{~b}$ & $13.01 \mathrm{c}$ \\
\hline Weedy check & $1025 \mathrm{c}$ & $4566.7 \mathrm{c}$ & $20.65 \mathrm{c}$ & $77.30 \mathrm{a}$ \\
\hline LSD & 117.79 & 714.35 & 2.16 & 2.60 \\
\hline CV $(\%)$ & 1.91 & 5.21 & 3.80 & 5.01 \\
\hline
\end{tabular}




\section{SUMMARY AND CONCLUSION}

Bread wheat is the most important food grain crops in the world in which its productivity has been limited due to biotic and abiotic constraints. Weed management practices such as promising herbicides are among the important methods for the management of weeds to improve wheat production and productivity. Therefore, the aim of the study was to evaluate the effects of post emergence broad leaf herbicides application on weed management and productivity of wheat.

Some of the traits studied were significantly affected by herbicides application but there is no significant difference among tested herbicides on plant height, stand count, spike length, number of seeds per spike and thousand grain weights except for weedy checks. The minimum number of dry biomass of weeds and highest weed control efficiency were recorded at application of Pyroxulam but no weed control at weedy check while the maximum numbers of dry biomass of weed were obtained from weedy checks. The maximum number of productive tillers and stand count was recorded at Pyroxulam treated plots. The maximum plant height was recorded from of weedy check while the maximum harvest index was observed at 2, 4-D.

Application of Florasulam + Aminopyrolid comparatively gave maximum grain yield and biological yield but low significant yield loss as compared to other tested herbicides. Herbicides having the ability of controlling various weed species gave better yield advantages as well as for good weed management over narrow spectrum herbicides. However, more yield advantages was obtained from application of broad spectrum herbicide Florasulam + Aminopyrolid which could be recommended for the test environment.

\section{REFERENCES}

[1] Abbas,S.H., Saleem,M.,Maqsood,M., Mujahid, M.Y. and Saleem, R.2009.Weed density and grain yield of wheat as affected by spatial arrangements and weeding techniques under rain fed conditions of Pothowar. Pakistan Journal of Agricultural Science. 46(4): 242-247.

[2] Ali, H., Tahir, M. and Nadeem, M.A.2014. Determining Critical Period of Weed Competition in Wheat under Different Tillage Systems.life.12(2):74-79.

[3] Ali,Y. and Awan,A.R.2004. Influence of salinity at seedling stage on yield and yield components of different rice lines. International Journal of Biotechnology.1: 175-179.

[4] Amare ,T., Sharma, J.J. and Kassahun, Z.2014. "Effect of Weed Control Methods on Weeds and Wheat (TriticumAestivum L.) Yield.” World Journal of Agricultural Research. vol. 2, no. 3 (2014): 124-128.

[5] Asad, M., Safdar, A., Ansar, M.R.,Ijaz, A., Suhaib, M. and Abuzar, M.K.2017. Weed and Wheat Dynamics Preceding Different Herbicide. Pakistan Journal of Agricultural Research. 30(4):346-355.

[6] Ashiq, Muhammad, N. and Ahmad, N. 2007. Comparative efficacy of different herbicides against broadleaved weeds in wheat. Pakistan Journal of Weed Science Research. 13(4): 149-156.

[7] Dalga D. 2016.Weed Dynamics and Yield of Bread Wheat (Triticum aestivum L.) in Response to Weed Management and Nitrogen Fertilizer Rates in Southern Ethiopia Science and Agriculture. 16 (1) : 8-19

[8] Davasenapathy,P.T, Remesh, B.2008. Efficiency indices for Agricultural Management Research. New Indian Publishing Agency, New Delhi India.pp. 576-64.

[9] Dixon, J, Braun, H.J, Crouch , J.H. 2009. Overview: Transitioning wheat research to serve future needs of developing world. In Wheat Facts and Futures,1-25 Pp. Dixon, J. Braun, H.J. Kosina, P. and Crouch, J.H. (Eds). CYMMIT, Mexico.

[10] Fazal, Munsif, Kawsar,Ali, Iftikhar and Khan,H.U. 2012.Efficacy of various herbicides against weeds and their impact on yield of spring wheat. Pakistan Journal of Weed Science Research.15(3): 191-198.

[11] Gebre-Mariam, H.2003. Wheat production and research in Ethiopia, IAR, Addis Ababa Ethiopia.

[12] Gomez, K.A. and Gomez, A.A.1984. Statistical procedures for agricultural research (2 ed.). John Wiley and sons, NewYork. 680p.

[13] Hussain, Z.,Marwat,K.B.,Munsif,F.,Samad,A. and Ali,K.2013.Evaluation of various herbicides and their combinations for weed control in wheat crop. Pakistan Journal of Botany. 45(1) : 55-59.

[14] Karlen, L.D., Buhler, D.D., Ellusbury, M.M. and Andrews, S.S.2002. Soil, weeds and insect management strategies for sustainable agriculture. Journal of Biological Science.2(1) :58-62.

[15]Khalil, Hassan, G., Ahmad, G. and Hussain,S.N.2008.Individual and combined effect of different weed management practices on weed control in Wheat. Pakistan Journal of Weed Science Research. 14 (4): 131139. 
[16] Marwat,K.B., Khan,A,.M ,Hashim,S.,Nawab,K.And Abdul Mateen,K.K.2011.Integrated Weed Management In Wheat Pakistan Journal of Botany. 43(1):625-633.

[17] Munsif,F., Ali,K.,Khan,I., Khan,H.U.and Anwar,M.2009.Efficacy of various herbicides against weeds and their impact on yield of maize. Pakistan Journal of Weed Science Research. 15(3):191-198.

[18] Nadeem, M.A.,Ali,A. and Tanveer,A.S.I.F.2006. Effect of different weed control practices and fertilizer levels on the weeds and grain yield of wheat. Pakistan Journal of Botany. 39(1):173.

[19] Pandey, I.B. and Dwivedi, D.K. 2007. Effect of planting pattern and weed-control methods on weed growth and performance of wheat (Triticum aestivum). Indian Journal of Agronomy. 52 (3) : 235-238.

[20] Safdar, M.E., Asif, M., Ali, A., Aziz, A., Yasin, M., Aziz, M., Afzal, M. and Ali, A. 2011. Comparative efficacy of different weed management strategies in wheat. Chilean journal of agricultural research. 71(2) :195-217.

[21] Sujoy,D.,Sarkar,A.K.,Bhattacharya,S.P.,Abhijit, S. 2006.Effect of various weed management practices in wheat. Environment and Ecology, 24: 620-622.

[22] Tana,T.,Lemlem,M.and Dejene,M.2018.Determination of Critical Period of Weed Competition in Bread Wheat Triticum aestivum L.at Haramaya,Eastern Ethiopia ,Doctoral dissertation,Haramaya University:1-92

[23] Tunio, S.D., Kaka, S.N., Jarwar, A.D.and Wagan, M.R.2004. Effect of integratedweed management practices on wheatyield. Pakistan Journal of Agricultural Engineering and Veterinary Science.2004; 20 (1): 5-10.

[24] Yared ,T., Obsa ,C., Kebna, A., Girma. T. 2018.Evaluation and Demonstration of Different Post-Emergence Herbicides for Controlling Wild Oat (Avena fatua L.) and Other Grass Weeds in Wheat (Triticum Spp) at Bore. Agricultural Research and Technology.16(4): 91-96.

[25]Zahoor, F., Malik, M.A., Mehmood, K.,Rasheed,M.,Ansar,R.,Hussain, M.,Kazmi,M.H. and Jamil, M.2012.Optimizing herbicide use in wheat (Triticum aestivum L.) under rain-fed conditions. African Journal of Agricultural Research. 7(35) :4858-4866.

Citation: Bogale Ayana and Meseret Ejeta, (2021). "Impact of Herbicides on Various Weed Flora in Wheat under Rainfed Production System", International Journal of Research Studies in Agricultural Sciences (IJRSAS), 7(7), pp. 1-9 DOI: http://dx.doi.org/10.20431/2454-6224.0707001

Copyright: ( 2021 Authors. This is an open-access article distributed under the terms of the Creative Commons Attribution License, which permits unrestricted use, distribution, and reproduction in any medium, provided the original author and source are credited. 